\title{
SPECIFIC REQUESTS AND THE PROSECUTORIAL DUTY TO DISCLOSE EVIDENCE: THE IMPACT OF UNITED STATES v. BAGLEY
}

Brady v. Maryland ${ }^{1}$ established that, as a matter of due process, a criminal defendant has an access right upon request to evidence within the prosecutor's possession that is both favorable and material to the defense. ${ }^{2}$ The extent of this constitutional right, however, depends on the definition of materiality. In United States v. Agurs, ${ }^{3}$ the Supreme Court created a two-tiered framework for determining materiality. With respect to evidence that the defense specifically requested, the test was whether the evidence "might have affected the outcome of the trial."4 With respect to generally requested evidence or evidence not requested at all, the standard was higher and less inclusive: evidence was material if it "create[d] a reasonable doubt which did not otherwise exist."s

In Agurs the Court imposed a lesser burden on the defendant in the specific request context because a specific request facilitates prosecutorial conipliance by providing notice of evidence that the defense lacks and perceives as important. ${ }^{6}$ Implicit in the Court's reasoning was the notion that suppression of evidence specifically requested by the defendant is fundamentally unfair and amounts to prosecutorial nisdealing. ${ }^{7}$

In United States v. Bagley, ${ }^{8}$ however, a divided Suprenie Court replaced the Brady-Agurs materiality framework with a single materiality standard.9 Under Bagley, evidence is material if there is a "reasonable probability" that it "would" alter the trial result. ${ }^{10}$ The Court characterized this standard as "sufficiently flexible" to cover both the specific request and general/no request contexts. ${ }^{11}$ Although it theoretically preserves a favored position for a defendant making a specific request,

1. 373 U.S. 83 (1963).

2. Id. at 87. A prosecutor's failure to disclose requested evidence that is both favorable and material entitles the defendant to a retrial. See id. at 85-87.

3. 427 U.S. 97 (1976).

4. Id. at 104 .

5. Id. at 112 .

6. Id. at 106-07.

7. See infra notes $159-62$ and accompanying text.

8. 105 S. Ct. 3375 (1985).

9. Id. at 3382-84.

10. Id. at 3384.

11. Id. 
the Bagley standard eliminates, as a practical matter, the advantage such a defendant possessed under the Brady-Agurs materiality standard.

The Bagley majority ignored the concern with notice and fairness that was thought in Agurs to justify a lower specific request materiality standard. ${ }^{12}$ Instead, Justice Blackmun ${ }^{13}$ focused on the notion that the defendant often suffers greater harm from nondisclosure after a specific request than he does after a general request, because nondisclosure in the former context is more likely to misleadingly represent to the defendant that the requested evidence does not exist. ${ }^{14}$ Seeking to address this concern, Justice Blackmun incorporated into the single materiality standard a requirement that reviewing courts consider any additional "adverse effects" the defendant suffers as a result of the prosecutor's failure to disclose evidence following a specific request. ${ }^{15}$ Justice Blackmun maintained that the defendant making a specific request would have an easier time deinonstrating materiahty because reviewing courts would consider these "specific" adverse effects. ${ }^{16}$ Only one lower court, however, has followed Justice Blackmun's instructions to consider whether the defense suffered any "specific" adverse effects. ${ }^{17}$ Three circuits, confused by the divided nature of the Bagley decision, have concluded that the Bagley Court intentionally adopted a standard that treats specific and general/ no requests the same. ${ }^{18}$ Two other circuits, while correctly concluding that the Bagley Court intended to accord favorable treatment to specific requests, have yet actually to apply the Bagley analysis by considering whether the defense suffered any "specific" adverse effects. ${ }^{19}$ This note will demonstrate that "specific" adverse effects cannot exist because nondisclosure following a specific request is no more likely to misleadingly represent to the defense that evidence does not exist than is nondisclosure following a general request. ${ }^{20}$ Furthermore, this note will denonstrate that consideration of the adverse effects of a nondisclosure's misleading representation to the defense that evidence does not exist will never help

12. See infra notes $163-65$ and accompanying text.

13. Announcing the Court's decision, Justice Blackmun, joined by Justice O'Connor, wrote a three-part opinion. Justice White, joined by Justice Rehnquist and Chief Justice Burger, concurred with parts I, II and portions of part III. Justice Marshall, joined by Justice Brennan, dissented. Justice Stevens also wrote a dissenting opinion. Justice Powell did not participate in the Court's decision.

14. See infra notes $105-06,163-65$ and accompanying text.

15. See infra notes 107-09, 148-50 and accompanying text.

16. See infra notes 108-09 and accompanying text.

17. See infra notes $133-36$ and accompanying text.

18. See infra notes $138-47$ and accompanying text.

19. See infra notes 124-32 and accompanying text.

20. See infra pp. 911-13. 
the defense prove materiality. ${ }^{21}$

This note begins with a discussion of the pre-Bagley materiality standard, tracing the origins of the prosecution's constitutional disclosure duty and focusing on the Brady-Agurs materiality framework. ${ }^{22}$ The note then examines the Bagley holding and the conflicting ways in which the courts of appeals have interpreted that holding. ${ }^{23}$ Finally, the note analyzes the Bagley standard in three steps. First, the theoretical operation of the new standard is examined and illustrated. ${ }^{24}$ Second, the Court's undiscussed shift away from the Brady-Agurs rationale is explored. ${ }^{25}$ The note concludes that notwithstanding the theoretical operation of the new standard, in practice a defendant making a specific request can claim no special adverse effects arising from nondisclosure.

\section{Materiality Before BagLEY: The BRADY-AGURS FRAMEWORK}

The origins of the prosecution's constitutional duty to disclose material evidence favorable to the accused are found in a series of three Supreme Court decisions: Mooney v. Holohan, ${ }^{26}$ Alcorta v. Texas, ${ }^{27}$ and Napue v. Illinois. ${ }^{28}$ Together, these three cases held that due process prohibits a prosecutor from intentionally using or failing to correct false testimony, even when the testimony relates solely to a witness's credibility. ${ }^{29}$

Brady v. Maryland ${ }^{30}$ significantly expanded the constitutional duties of the prosecution by requiring that the prosecution disclose to the defense material, favorable evidence upon request. ${ }^{31}$ In Brady, the de-

21. See infra pp. 913-14.

22. See infra notes $26-70$ and accompanying text.

23. See infra notes 71-147 and accompanying text.

24. See infra notes $148-51$ and accompanying text.

25. See infra notes $154-65$ and accompanying text.

26. 294 U.S. 103 (1935) (per curiam).

27. 355 U.S. 28 (1957) (per curiam).

28. 360 U.S. 264 (1959).

29. In Mooney, the Court held that a prosecutor's intentional use of perjured testimony violates a defendant's right to due process. Mooney, 294 U.S. at 112. The Court reasoned that such prosecutorial deception was "inconsistent with the rudimentary demands of justice." Id..

In Alcorta, the Court extended the Mooney rule by concluding that a prosecutor's knowing failure to correct inculpatory, perjured testimony violates due process. Alcorta, 355 U.S. at 31-32. The Court gave greater scope to the duty to correct false testimony in Napule. There the Court held that a prosecutor's failure to correct false testimony violates due process even when the testimony relates solely to a witness's credibility. Napue, 360 U.S. at 269 . The Court justified this broader rule by reasoning that "It]he jury's estimate of the truthfuiness and reliability of a given witness nay well be determinative of guilt or innocence." Id.

30. 373 U.S. 83 (1963).

31. Id. at 87 . 
fendant was sentenced to death for first-degree murder. ${ }^{32}$ Despite the defendant's pretrial specific request for all the extrajudicial statements of a codefendant, the prosecution withheld the codefendant's statement in which he admitted committing the homicide. ${ }^{33}$

The Supreme Court held that the prosecution's nondisclosure of the requested evidence denied Brady due process, reasoning that the jury might not have invoked the death penalty had it heard this evidence. ${ }^{34}$ The Court concluded that "the suppression by the prosecution of evidence favorable to an accused upon request violates due process where the evidence is inaterial either to guilt or pumshment, irrespective of the good faith or bad faith of the prosecution." 35 In support of its holding, the Court relied on the concern for due process elaborated in Mooney, stating that "[t] he principle of Mooney v. Holohan is not punishment of society for niisdeeds of a prosecutor but avoidance of an unfair trial to the accused." ${ }^{36}$ Thus the Brady Court determined that fairness required not merely that the prosecution refrain froin misleading the jury through a presentation of false facts, but also that the prosecution disclose material, favorable evidence upon request of the defense. ${ }^{37}$

Brady, however, left two important questions unanswered: the first concerned the definition of "material," 38 and the second concerned whether the standard enunciated applied only if a specific request for evidence had been made. ${ }^{39}$

The Court addressed both of these questions in United States $v$. Agurs. ${ }^{40}$ In Agurs a jury convicted the defendant of second-degree inurder. ${ }^{41}$ At trial, the defense attorney presented a theory of self-defense, offering evidence of the defendant's screams for help and the victim's

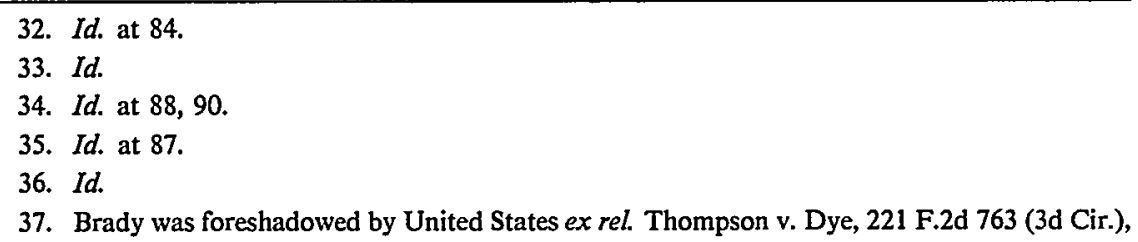
cert. denied, 350 U.S. 875 (1955), and United States ex rel. Almeida v. Baldi, 195 F.2d 815 (3d Cir. 1952), cert. denied, 345 U.S. 904 (1953).

38. Professor Babcock explains that "[1]eading precedents understood 'materiality' to correspond to a certain quantum of likelihood that the undisclosed evidence would have affected the verdict." Babcock, Fair Play: Evidence Favorable to an Accused and Effective Assistance of Counsel, 34 StAN. L. REV. 1133, 1146 n.46 (1982).

39. Justice Fortas argued that no specific request should be required. See Giles v. Maryland, 386 U.S. 66, 102 (1967) (Fortas, J., concurring). Defense lawyers assumed that Brady required no specific request and immediately began making general requests for all Brady material. Sce Babcock, supra note 38 , at $1143-45$.

40. 427 U.S. 97 (1976).

41. Id. at 98 . 
prior possession of two knives. ${ }^{42}$ After the conviction, the defense attorney moved for a new trial on the ground that the prosecution had failed to disclose the victim's record of criminal violence, 43 evidence that the defense attorney had not requested before the trial. ${ }^{44}$ The United States Court of Appeals for the District of Columbia Circuit accepted the defendant's argument and held that the evidence was sufficiently material because the jury might have returned a different verdict had the evidence been received. 45

The Supreme Court reversed. The Court distinguished three contexts in which the Brady disclosure duty arguably could apply ${ }^{46}$ and articulated a materiahty standard for each. First, the Court described the Mooney situation in which "the undisclosed evidence demonstrates that the prosecution's case includes perjured testimony and the prosecution knew, or should have known, of the perjury." 47 Such a situation is reversible error, the Court explained, "if there is any reasonable likelihood that the false testimony could have affected the judgment of the jury." 48

The Court described the second context in which the Brady disclosure duty applied as the situation presented in Brady - prosecutorial nondisclosure of specifically requested evidence. ${ }^{49}$ Although Brady never exphicitly articulated the contours of its standard, the Agurs Court said that a fair analysis of Brady "indicates that implicit in the requirement of materiality is a concern that the suppressed evidence might have affected the outcome of the trial."so

The Court identified the third context as prosecutorial nondisclosure in response to a general request or no request at all.51 According to the Court, this third situation applied to the Agurs facts ${ }^{52}$ and required a higher, less inclusive materiality standard: ${ }^{53}$ undisclosed evidence is material in this context if it "creates a reasonable doubt that did not otherwise exist." 54 For the Court, the difference between the Brady and the Agurs contexts was the degree of notice to the prosecutor. With a specific request, the Court einphasized, the prosecutor understands exactly

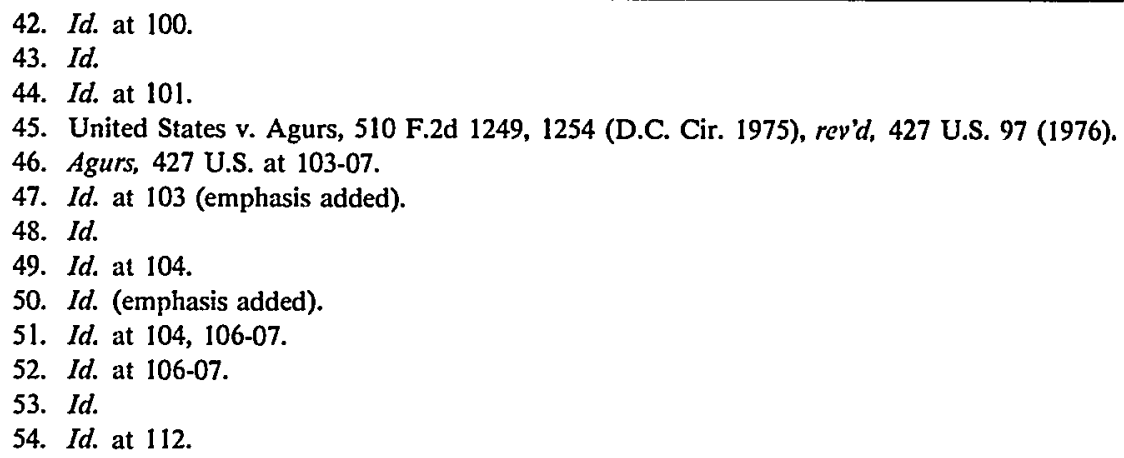


what the defense desires.55 A general request, conversely, "really gives the prosecutor no better notice than if no request is made."56 The Court thus reasoned that the constitutional disclosure duty should be less in the case of a general or no request than in the specific request situation presented in Brady. ${ }^{57}$

In its effort to define the materiality standard for the general request, the Court reviewed standards previously used by lower courts. ${ }^{58}$ The United States Court of Appeals for the District of Columbia Circuit had used a standard that required disclosure of evidence that might affect the jury's verdict. ${ }^{59}$ The Supreme Court rejected this standard as too favorable to the defense. ${ }^{60}$ On the other hand, the Court rejected as too burdensome for the defense the standard applicable to evidence discovered from a neutral source after trial. ${ }^{61}$ That standard required a new trial if the new evidence would probably produce an acquittal in a new trial.62 The Court emphasized that if the "new evidence" standard were used to define materiality, "there would be no special significance to the prosecutor's obligation to serve the cause of justice."63

After considering these two materiality standards, the Court established the following standard for situations in which no request or only a general request has been made: undisclosed evidence is material if it "creates a reasonable doubt that did not otherwise exist."64 The Court thus settled on a materiality standard that reflected its "overriding concern with the justice of the finding of guilt."65 Applying this new stan-

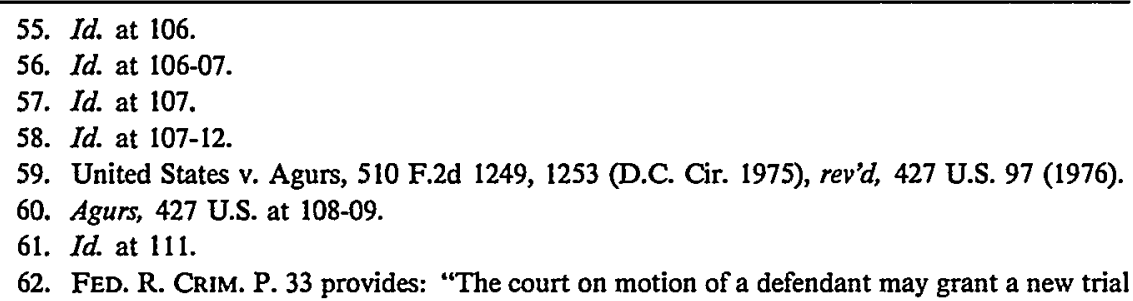
to him in the interest of justice." Most courts have interpreted this rule as requiring a new trial if the new evidence would probably produce an acquittal in a new trial. See, e.g., United States v. Weninger, 624 F.2d 163, 167 (10th Cir.), cert. denied, 449 U.S. 1012 (1980); United States v. Mackin, 561 F.2d 958, 961 (D.C. Cir.), cert. denied, 434 U.S. 959 (1977); United States v. Garner, 529 F.2d 962, 969 (6th Cir.), cert. denied, 426 U.S. 922, 429 U.S. 850 (1976).

63. Agurs, 427 U.S. at 111.

64. Id. at 112 (emphasis added). Despite some disagreement, most commentators agree that the Agurs opinion stated this materiality standard clearly. See Note, A Prosecutor's Duty to Disclose Promises of Favorable Treatment Made to Witnesses for the Prosecution, 94 HARV. L. REV. 887, 893 (1981); Comment, The Prosecutor's Duty of Disclosure: From Brady to Augers and Beyond, $69 \mathrm{~J}$. CRIM. L. \& CRIminology 197, 204 (1978) [hereinafter Comment, Prosecutor's Duty]; Comment, Prosecutor's Duty to Diselose Reconsidered, 1976 WASH. U.L.Q. 480, 488 n.57 [hereinafter Comment, Prosecutor's Duty Reconsidered ]; cf. Babcock, supra note 38, at 1175-77 (arguing that Agurs "tells us what the standard for review is not").

65. Agurs, 427 U.S. at 112. 
dard to the facts in Agurs, the Court held that the evidence did not create a reasonable doubt that did not otherwise exist. ${ }^{66}$

Agurs, in conjunction with Brady, yielded a straightforward framework for determining the proper materiality standard to be applied to given evidence. ${ }^{67}$ First, the reviewing court was to decide whether the case involved (1) the knowing use of perjury, (2) nondisclosure in response to a specific request, or (3) nondisclosure in response to a general or no request. Once the court determined the applicable context, the materiality standard would be immediately identifiable. For the first category, evidence would be material if there was "any reasonable likelihood that the false testimony could have affected the judgment of the jury." 68 For the second category, evidence would be material if it "might have affected the outcome of the trial." 69 For the third category, evidence would be material if it created "a reasonable doubt which did not otherwise exist." 70

\section{The Demise of The BRADY-AgURS FRAMEWorK: UNITED STATES V. BAGLEY}

In United States v. Bagley, ${ }^{71}$ the Supreme Court replaced the BradyAgurs materiality framework with a single "flexible" standard. Announcing the judgment of the Court, Justice Blackmun, in the portion of his opinion that was joined by a majority of the Court, determined that Agurs had left unresolved the materiality standard applicable to specifically requested evidence and proceeded to define it.72 By contrast, Justice Stevens, who had written the opinion for the Court in Agurs, argued in dissent that the Court had already resolved the specific request standard in Brady and Agurs. ${ }^{73}$

Bagley was indicted on fifteen charges of violating federal narcotics and firearm statutes. ${ }^{74}$ Before trial, Bagley's attorney filed a discovery motion specifically requesting "any deals, promises or inducements made

66. Id. at 113-14.

67. One commentator argues that the determination of the proper materiality standard is just the beginning of a court's analysis. The next, more complex step is the court's application of the materiality standard to the given evidence. Several factors must be considered in this second step: favorability, admissibility, the extent to which evidence is cumulative, and weight of the evidence. See Comment, Prosecutor's Duty, supra note 64, at 225.

68. Agurs, 427 U.S. at 103.

69. Id. at 104 .

70. Id. at 112 .

71. 105 S. Ct. 3375 (1985).

72. Id. at 3381 . See infra notes $95-98$ and accompanying text.

73. Bagley, $105 \mathrm{~S}$. Ct. at 3399 (Stevens, J., dissenting). See infra notes 110-13 and accompanying text.

74. Bagley, $105 \mathrm{~S}$. Ct. at 3377. 
to witnesses in exchange for testimony." 75 The government responded that no "deals, promises or inducements" had been made to either of its two principal witnesses, O'Connor or Mitchell, each of whom had assisted the Federal Bureau of Alcohol, Tobacco and Firearms (ATF) in an undercover investigation of Bagley. ${ }^{76}$ At the nonjury trial, O'Connor and Mitchell gave testimony relating to both the firearms and the narcotics charges. ${ }^{77}$ The Court found Bagley guilty on the narcotics charges, but acquitted him on the firearms charges. ${ }^{78}$

After the trial, in response to his requests made pursuant to the Freedom of Information Act ${ }^{79}$ and the Privacy Act of 1974, ${ }^{80}$ Bagley received copies of ATF form contracts signed by Mitchell and O'Connor. The contracts guaranteed payment "commensurate with services and information rendered." 81 Bagley moved to have his sentence vacated, alleging that the government's failure to disclose this specifically requested evidence constituted a violation of due process under Brady. 82

The motion came before the same district court judge who had presided at Bagley's trial. 83 After an evidentiary hearing before a magistrate, ${ }^{84}$ the district court ruled that had the existence of the ATF contract been disclosed to it during trial, its finding would not have been affected. ${ }^{85}$

The United States Court of Appeals for the Ninth Circuit reversed 86 on the theory that the government's nondisclosure impaired Bagley's right to confront hostile witnesses. ${ }^{87}$ The court, relying on the Supreme Court's decision in Davis v. Alaska, ${ }^{88}$ held that "the denial of the 'right of effective cross-examination' was 'constitutional error of the first magnitude' requiring automatic reversal." 89

The Supreme Court, in turn, reversed the court of appeals, holding

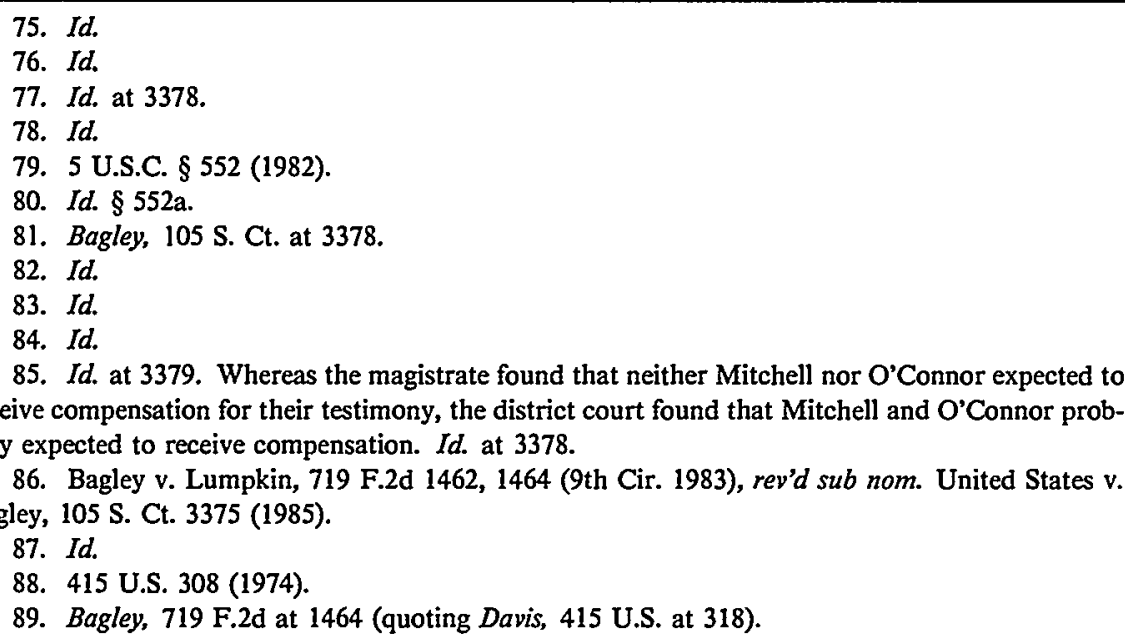


that the Ninth Circuit had misapplied Davis. ${ }^{90}$ Justice Blackmun, in the part of his opinion that was joined by a majority of the Court, distinguished Davis, pointing out that there the trial judge had entirely disallowed the cross-examination of a crucial prosecution witness.91 In contrast, the trial court in Bagley had not directly restricted the scope of cross-examination; rather, "[ $t]$ he constitutional error, if any, in this case was the Government's failure to assist the defense by disclosing information that might have been helpful in conducting the cross-examination."92 Justice Blackmun explained that such nondisclosure is constitutional error only when the evidence is "material in the sense that its suppression undermines confidence in the outcome of the trial."93

Justice Blackmun next considered the appropriate standard for assessing the materiality of the suppressed evidence. ${ }^{94} \mathrm{He}$ examined the Brady-Agurs framework ${ }^{95}$ and concluded that the Agurs Court never defined the materiahity standard applicable in the specific request context. 96 In his view, Agurs went no further than to suggest that the specific request materiality standard should be more lenient than the general/no request standard.97 According to Justice Blackmun, the Agurs Court's description of materiaity as evidence that "might have affected the outcome of the trial" should not be understood as indicating a materiality standard. ${ }^{98}$

To define the specific request materiality standard, Justice Blackmun looked to two earlier Supreme Court cases, Strickland v. Washington 99 and United States v. Valenzuela-Bernal. 100 Both cases had discussed Agurs but neither involved prosecutorial nondisclosure. ${ }^{101}$ Jus-

90. Bagley, 105 S. Ct. at $3379,3381$.

91. Id. at 3381 .

92. Id.

93. Id.

94. Id. at 3381-84 (opinion of Blackmun, J., joined by O'Connor, J.) A majority of the Court agreed with this portion of Justice Blackmun's opinion. Justice White, while joining only parts I and II, agreed in his concurrence with Justice Blackmun's conelusion as to the appropriate materiality standard. Id. at 3385 (White, J., concurring) ("I also agree with Justicc Blackmun that ... . "evidence is material only if there is a reasonable probability that, had the evidence been disclosed to the defense, the result of the proceeding would have been different." "). Justice White's concurring opinion was joined by Chief Justice Burger and Justice Rehnquist.

95. Id. at 3382-83 (opinion of Blackmun, J., joined by O'Connor, J.).

96. Id.

97. Id.

98. Id. at 3383 n. 12 .

99. 466 U.S. 668 (1984).

100. 458 U.S. 858 (1982).

101. Strickland involved the standard of materiality necessary to prove that defense counsel's ineffectiveness deprived the defendant of due process. Strickland, 466 U.S. at 671 . ValenzuclaBernal considered the standard of materiality necessary to demonstrate constitutional error when favorable witnesses are deported as illegal aliens. Valenzuela-Bernal, 458 U.S. at 860. 
tice Blackmun selected the materiality standard formulated in Strickland. ${ }^{102}$ The Strickland Court had held that a defense counsel's unprofessional errors constitute a due process violation when "there is a reasonable probability that, but for [the] errors, the result of the proceeding would have been different. A reasonable probability is a probability sufficient to undermine confidence in the outcome." 103 The Bagley majority thus adopted Strickland's "reasonable probability" standard for use in the prosecutorial nondisclosure context.

The Bagley majority declared that the Strickland standard was "sufficiently flexible" to cover both the specific request and the general/no request contexts. ${ }^{104}$ Justice Blackmun believed that prosecutorial nondisclosure in response to a specific request often injures the defense more than nondisclosure in response to a general/no request. ${ }^{105}$ According to Justice Blackmun, nondisclosure in response to a specific request "not only deprives the defense of certain evidence, but has the effect of representing to the defense that the evidence does not exist. In rehance on this misleading representation, the defense might abandon lines of independent investigation, defense, or trial strategies that it otherwise would have pursued." 106 But Justice Blackmun claimed that despite the greater potential for injury to the defense in the specific request context, a separate, more favorable specific request materiahty standard was not necessary. ${ }^{107}$ Instead, Justice Blackmun maintained that the Strickland flexible standard sufficed because "under the Strickland formulation the reviewing court may consider directly any adverse effect that the prosecutor's failure to respond might have had on the preparation or presentation of the defendant's case."108 Justice Blackmun reasoned that the Strickland standard would allow a reviewing court to compensate for any additional adverse effects in the specific request context by adding them to the overall detrimental effect of nondisclosure. ${ }^{109}$

Justice Marshall and Justice Stevens each wrote vigorous dis-

102. Bagley, 105 S. Ct. at 3384 (opinion of Blackmun, J., joined by O'Connor, J.). See also id. at 3385 (opinion of White, J., joined by Burger, C.J. \& Rehnquist, J.).

103. Strickland, 466 U.S. at 694.

104. Bagley, $105 \mathrm{~S}$. Ct. at 3384 (opinion of Blackmun, J., joined by O'Connor, J.); see also id. at 3385 (opinion of White, J., joined by Burger, C.J. \& Rehnquist, J.).

105. Id. at 3384 (opinion of Blackmun, J., joined by O'Connor, J.).

106. Id.

107. Id.

108. Id.

109. Id. Whether or not Blackmun conceived of other adverse effects from specific request nondisclosure is unclear. Blackmun's entire analysis of additional adverse effects in the specific request context focuses on the defense being misled into believing the evidence did not exist. Bagley, $105 \mathrm{~S}$. Ct. at 3384 (opinion of Blackmun, J., joined by O'Connor, J.). See infra note 150. 
sents. ${ }^{110}$ Justice Stevens, who had written the majority opinion in Agurs, leveled two attacks. First, he argued that the majority had misread Agurs. ${ }^{111}$ Justice Stevens asserted that the Agurs Court had simply restated the Brady specific request materiality standard and had concerned itself with determining whether to extend that standard to cover the general/no request situation. ${ }^{12}$ In Justice Stevens's view, the Bagley majority should have simply applied the Brady specific request materiality standard which Agurs and Strickland had left untouched. ${ }^{113}$

Justice Stevens's second attack assailed the weakness of the majority's new materiality standard. ${ }^{114} \mathrm{He}$ contended that actively misleading the defense through nondisclosure of specifically requested evidence is as serious as perjury. ${ }^{115}$ In Justice Stevens's view, the standard enunciated by the majority would madequately deter such prosecutorial misconduct. ${ }^{116}$ The majority's new standard "reduce[d] the significance of deliberate prosecutorial suppression of potentially exculpatory evidence to that merely of one of numerous factors that 'may' be considered by a reviewing court." 117

Justice Stevens and Justice Marshall both argued that the majority's standard gave the prosecutor too much discretion,"118 "legitimizing the nondisclosure of clearly favorable evidence." 119 Justice Marshall maintained that the new materiality standard is so high and noninclusive that, even in the specific request context, prosecutors are encouraged not to disclose but instead "to gamble, to play the odds, and to take a chance that evidence will later turn out not to have been potentially dispositive." 120

\section{The CONFLICTING INTERPRETATIONS OF BAGLEY}

All courts addressing the Bagley standard have agreed that Bagley abandoned the Brady-Agurs materiality framework. ${ }^{121}$ However, courts have disagreed over whether the Bagley standard treats specific requests

110. Id. at 3385 (Marshall, J., dissenting); id. at 3397 (Stevens, J., dissenting).

111. Id. at 3399 (Stevens, J., dissenting).

112. Id. at 3397-99.

113. Id. at 3399.

114. Id. at 3400 .

115. $I d$.

116. $I d$.

117. $I d$.

118. See id. at $3400 ; i d$. at 3393 (Marshall, J., dissenting).

119. Id. at 3393 (Marshall, J., dissenting).

120. Id.

121. See, e.g., United States v. Srulowitz, 785 F.2d 382, 388 (2d Cir. 1986); Government of Virgin Islands v. Martinez, 780 F.2d 302, 310 (3d Cir. 1986); Bond v. Procunier, 780 F.2d 461, 464 (4th Cir. 1986). 
differently than general/no requests. The United States Courts of Appeals for the Third and Fifth Circuits as well as the United States Court of Military Appeals have concluded that the Bagley Court intended favorable treatment for specific requests; the Third and Fifth Circuits, however, have not actually applied the Bagley analysis by considering whether the defense suffered any "specific" adverse effects. 122 The United States Courts of Appeals for the Second, Seventh, and Eighth Circuits, on the other hand, have concluded that the Bagley court intentionally adopted a standard that treats specific and general/no requests the same. ${ }^{123}$

The United States Court of Appeals for the Third Circuit has interpreted Bagley as instructing courts to treat specific requests more favorably by considering adverse effects that arise because the undisclosed evidence was specifically requested. In Government of Virgin Islands $v$. Martinez, ${ }^{124}$ the Third Circuit held that evidence under Bagley, whether or not specifically requested, is material when a reasonable probability exists that its disclosure would have altered the trial result. ${ }^{125}$ The court emphasized, however, that any adverse effects on the defense's preparation or presentation of its case that arise from the prosecution's nondisclosure had to be considered because adverse effects were "more likely" in the specific request context. ${ }^{126}$ Specifically, the court noted that the nondisclosure becomes more misleading as the request becomes more specific. ${ }^{127}$ The court remanded, directing the district court to apply the new Bagley standard and consider whether the evidence was specifically requested and whether there were "specific" adverse effects. ${ }^{128}$ One other decision by the Third Circuit and two decisions by district courts in the Third Circuit have addressed Bagley's treatment of specific requests; each decision is consistent with the Martinez holding. ${ }^{129}$

\footnotetext{
122. See infra notes $124-37$ and accompanying text.

123. See infra notes $138-47$ and accompanying text.

124. 780 F.2d 302 (3d Cir. 1986).

125. Id. at $306-07,307$ n. 5,310 .

126. Id. at 307.

127. Id. at $307 \mathrm{n.5}$ ("[T] ciently specific to put the prosecution on notice ... and to contribute to the misleading effects of non-disclosure.").

128. Id. at 311.

129. In United States v. Pflaumer, 774 F.2d 1224 (3d Cir. 1985), cert. denied, 106 S. Ct. 1263 (1986), a case involving the materiality of undisclosed, specifically requested evidence, the Third Circuit noted that Bagley abandoned the Brady-Agurs framework, "significantly" changing the materiality standard for specifically requested evidence. $I$ d. at 1226 . The court understood Bagley to stand for the proposition that specifically requested evidence is material if a reasonable probability exists that its disclosure would have altered the trial result. Although it acknowledged that the Bagley Court intended the standard to be flexible, id., the court never discussed the manner in which the standard's flexibility operated. Thus, in holding the evidence not "material" under Bagley, the
} 
In Lindsey v. King ${ }^{130}$ the United States Court of Appeals for the Fifth Circuit also read Bagley as treating specific requests more favorably. Without discussing the majority's treatment of specific requests, the court concluded that the Justices agreed in Bagley "that reversal for suppression of evidence by the government is most likely where the request for it was specific."131 However, because it found that the specifically

court simply applied the "reasonable probability" standard without attempting to understand the relevance of the request's specificity. Id. at 1230.

Each of the two district courts in the Third Circuit that addressed the question of how Bagley treats specific requests differently from general/no requests interpreted Bagley as the Third Circuit later did in Martinez. In United States v. Alberici, 618 F. Supp. 660 (E.D. Pa. 1985), the district court struggled with the Bagley decision. The court pointed out that Bagley replaced the old BradyAgurs framework with a new fiexible standard which somehow treated specific request more favorably. Id. at 668. The court found the Bagley opinions confusing. Noting that Justice White's concurrence never explicitly endorsed Blackmun's instruction that courts consider "specific" adverse effects, the Alberici court concluded that the Bagley decision never articulated a precise standard for specific requests; Bagley "apparently consign[ed] such evaluation to the reviewing court's discretion, that discretion being limited, of course, by the Bagley standard." Id. at 668 .

Seeking guidance from Bagley on how to evaluate the significance of a request's specificity, the district court attempted to synthesize the four Bagley opinions. The district court recognized that Justice Blackmun expected courts to consider all adverse effects, including those that arise because the request was specific. Id. The court then pointed out that Justice White only endorsed "Blackmun's characterization of the standard as a 'flexible' one, and appeared to suggest that any elaboration of the implications of this flexibility should be left to the lower courts to determine in accordance with the facts before them." Id. at 668-69. Finally, the court recognized that Justice Marshall thought specific requests deserved greater protection than the flexible standard adopted and that Justice Stevens argued that the new standard did not adequately remedy the harmful effects of nondisclosure in response to specific requests. Id. at 669. The district court determined that five Justices saw the need to address adverse effects from specific requests (Blackmun, O'Connor, Marshall, Brennan, and Stevens) and that five saw the new standards as "sufficiently flexible to accomodate the implications of a specific request" (Elackmun, O'Connor, White, Burger, and Rehnquist). The court then concluded that it would identify which requests were specific before applying the reasonable probability standard. $I d$.

The court, however, never resolved for itself how the flexibility in the standard should operate. After identifying the specifically requested evidence, the court did not need to analyze rigorously its materiality, since'the evidence was unfavorable, of extremely little probative value, or had been available to the defense at trial. Id. at 672-77.

In Carter v. Rafferty, 621 F. Supp. 533 (D.N.J. 1985), the district court described Bagley's single standard as

semantical ... because in order to assure that the standard has sufficient flexibility, certain factors must be weighed in determining whether there is a "reasonable probability." The [Bagley] Court noted, for example, that the more specific the request for evidence "putting the prosecutor on notice of its value," the more reasonable it is for the defense to assume from the nondisclosure that the evidence does not exist, and to make pretrial and trial decisions on the basis of this assumption. Thus, Bagley's instruction gives birth to yet another sliding scale: the more adverse the effect of the prosecution's failure, the more likely it is that the suppressed evidence will undermine confidence in the outcome.

Id. at 549-50. Although the district court read Bagley in this way, the court failed in its analysis of the materiality of the evidence at issue to discuss the possibility of adverse effects resulting from the request's specificity. Id. at 554-58.

130. 769 F.2d 1034, 1041 (5th Cir. 1985).

131. Id. 
requested evidence at issue was material, the Fifth Circuit did not articulate the manner in which the specific request made the finding of materiality more likely. ${ }^{132}$

In United States v. Eshalomi, 133 the United States Court of Military Appeals treated Justice Blackmun's imstruction to consider "specific" adverse effects as the effective holding of Bagley. The Eshalomi court concluded that the prosecution's nondisclosure of specifically requested evidence misrepresented to the defense that evidence did not exist. ${ }^{134}$ The court emphasized that "Justice Blackmun cautioned that an incomplete response to a defense request for evidence has the effect of misrepresenting that evidence does not exist." 135 The court noted that "under Justice Blackmun's view, a specific request for undisclosed evidence bolsters the defense case, because 'an imcomplete response to a specific request not only deprives the defense of certain evidence, but has the effect of representing to the defense that the evidence does not exist." "136 In concludimg that the evidence was material, the court determined that the defense suffered this adverse effect and added it to the overall detrimental effect of the nondisclosure. ${ }^{137}$

In contrast to the Third Circuit, Fifth Circuit, and the Court of Miltary Appeals, three circuits have interpreted the Bagley standard as treating specific requests and general/no requests the same. In United States v. Jackson, 138 the United States Court of Appeals for the Seventh Circuit concluded that Bagley abandoned any distinction between specific and general/no requests. ${ }^{139}$ The Jackson court explained that although Brady-Agurs required an inquiry into the request's specificity, 140 such inquiry "need no longer concern us . . . since under Bagley the reasonable probability standard is applicable irrespective of whether a defendant specifically requested exculpatory evidence."141

132. Id. at 1041-43.

133. No. 49,789 (C.M.A., Oct. 14, 1986) (LEXIS, Miltry library, CMA file).

134. Id. (quoting Bagley, $105 \mathrm{~S}$. Ct. at 3384).

135. Id.

136. Id.

137. $I d$.

138. 780 F.2d 1305 (7th Cir. 1986).

139. Id. at 1309-10.

140. Id. at 1310 .

141. Id. In two other opinions, the Seventh Circuit also concluded that Bagley gave no preferential treatment to specific requests. In United States ex rel. Smith v. Fairman, 769 F.2d 386 (7th Cir. 1985), the court found it unnecessary to determine whether the defense request was specific, not only because the evidence was clearly material under any standard, but also because "Bagley suggests that there is now a single standard of materiality." Id. at 392-93. Similarly, in United States v. Balistrieri, 779 F.2d 1191 (7th Cir. 1985) the court stated that "the distinction between general and specific requests drawn in United States $v$. Agurs has apparently been overruled [by Bagley]." Id. at 1222 n.36. 
In United States v. Srulowitz, 142 the United States Court of Appeals for the Second Circuit agreed with the Seventh Circuit's reading of Bagley. In Srulowitz, the court, without additional discussion, explained that Bagley

dispelled a suggestion lurking in Agurs that the concept of materiality might differ depending on whether the defendant had made a specific request for the undisclosed evidence, or a general request for exculpatory evidence, or no request at all. ... [T]he Bagley Court ruled that whether or not any request for exculpatory material had been made, undisclosed "evidence is material only if there is a reasonable probability that, had the evidence been disclosed to the defense, the result of the proceeding would have been different."143

The United States Court of Appeals for the Eighth Circuit has also apparently concluded that Bagley abandoned the specific/general distinction. In United States v. Ben M. Hogan, Co., 144 the court acknowledged that a decision regarding a request's specificity had been necessary under Brady-Agurs because specific requests were reviewed under a separate standard. ${ }^{145}$ The court concluded that under Bagley, however, one materiality standard apphed "irrespective of the specificity of a request for evidence made by the defense."146 Although the court did not expressly reject the interpretation that Bagley treats specific requests favorably within the single standard, it did imply that a request's specificity was no longer relevant at all. ${ }^{147}$

\section{The Bagley MATERIALITY STANDARD: THEORY VERSUS REALITY}

In theory, the Bagley materiality standard does treat specific requests more favorably by instructing courts to consider additional adverse effects that arise from nondisclosure following specific requests. To read this instruction out of Bagley and disregard additional adverse effects is to ignore the theory of that opinion. Yet this is not to say that

142. 785 F.2d 382 (2d Cir. 1986).

143. Id. at 388 (quoting Bagley, $105 \mathrm{~S}$. Ct. at 3384).

144. 769 F.2d 1293 (8th Cir. 1985).

145. Id. at 1299.

146. Id.

147. When contrasting the Brady-Agurs standard with the Bagley standard, the court mentioned that Brady-Agurs required an initial determination of whether the request was specific or general. Id. The court, applying Bagley, however, did not determine whether the evidence was specifically requested. Instead, the court proceeded directly to the materiality issue. Id.

In a subsequent Eighth Circuit case, Fryer v. Nix, 775 F.2d 979 (8th Cir. 1985), the court considered the materiality of undisclosed, unrequested evidence. Since the evidence was clearly not specifically requested, the court did not need to address the distinction between specific and general/ no requests. Id. Thus, the court's silence on the issue is not helpful in determining the Eighth Circuit's position. 
application of the Bagley "adverse effects" standard necessarily benefits the defendant who makes a specific request. The concept of additional adverse effects is a creation of the Bagley Court. Brady and Agurs never contemplated these "specific" adverse effects, but instead justified favorable treatment for specific requests on other grounds. As will be demonstrated below, logic compels the conclusion that no additional adverse effects arise in the specific request context. Accordingly, the Bagley standard in practice provides no advantage to the defendant who makes a specific request.

\section{A. The Bagley Materiality Standard in Theory: The Advantage of the Specific Request.}

The Bagley materiality standard treats specific and general/no requests the same except to the extent that reviewing courts are instructed to consider the additional adverse effects from nondisclosure that may arise in the specific request context. ${ }^{148}$ Although Justice Blackmun did not expressly say so, these additional adverse effects are theoretically distinct froin the two principal forms of injury suffered by the defense in all situations involving nondisclosure of evidence: (1) the denial to the defense of the persuasive force of the evidence itself; and (2) the denial of the derivative benefits of the evidence. ${ }^{149}$ According to Justice Blackinun, the additional adverse effects arising froin nondisclosure following a specific request are caused by the nondisclosure's inisleading representation that the requested evidence does not exist. ${ }^{150}$

A hypothetical loosely based on the Bagley facts illustrates these three types of adverse effects. Suppose defense counsel specifically requests any evidence that may show that the government induced its only witness to investigate and help convict the defendant. In response to the request, the government fails to disclose a contract that guaranteed pay-

148. See supra notes $104-09$ and accompanying text.

149. Some courts have required disclosure of inadmissible evidence that would lead to admissible material evidence. See, e.g., United States v. Ahmad, 53 F.R.D. 186, 193 (M.D. Pa. 1971). One commentator believes that the Ahmad approach is in line with the tenor of the Agurs opinion. Comment, Prosecutor's Duty, supra note 64, at 210-11. Professors Lafave and Israel, however, believe that Agurs rejected a duty to disclose inadmissible evidence that would lead to admissible material evidence. W. Lafave \& J. IsRael, Criminal Procedure § 19.5, at 759-60 (1985).

150. Bagley, $105 \mathrm{~S}$. Ct. at 3384. Justice Blackmun's opinion instructs courts to consider any adverse effects. The opinion could thus be read as contemplating "specific" adverse effects other than the adverse effect of the defense being misled into believing the evidence does not exist. But since no other "specific" adverse effects appear plausible and since Blackmun's entire rationale is based on the possibility of the defense being misled, this note will treat "specific" adverse effects as being exclusively composed of the adverse effects of the defense being misled into believing the evidence does not exist. 
ment to the witness and his partner on the condition that their investigation led to the defendant's conviction. The defendant is convicted.

On review, the court correctly determines that under Bagley it must consider whether the defense suffered the three kinds of adverse effects that separately, or in the aggregate, might have had a material effect on the trial result. The reviewing court finds that the defense suffered the first adverse effect, inability to present the evidence, in that the defense could not present the contract as evidence that the witness was biased or was motivated by a pecumary interest. The court also finds that the defense suffered the second adverse effect, denial of derivative benefits, in that the defense could not derive further favorable evidence from the contract. The reviewing court reasons that without access to the contract, the defense was unable to notice the partner's name on the contract, interview him, and thereby discover that his testimony would contradict the government's witness. The court further finds that the defense suffered the third adverse effect in that nondisclosure of the inducement evidence following a specific request misleadingly represented to the defense that no inducement evidence existed. In finding this third adverse effect, the court reasons that the defense abandoned its impeachment strategy because of this misleading representation, and therefore made no attempt to uncover other available evidence of inducement or to pursue the point on cross-examination. The court reasons further that, seemg no other alternative but to try for sympathy, the defense resorted to putting the defendant on the stand, resulting in grave injury to the defense from a devastating cross-examination. ${ }^{151}$

It is through consideration of the third kind of adverse effect-the misleading representation that the requested evidence does not existthat the Bagley standard theoretically treats specific requests more favorably and preserves an advantage for defendants making specific requests. Before considering whether in practice, as opposed to in theory, defendants making specific requests can bolster their case by arguing that they suffered this third type of adverse effect, it is useful to reiterate that the idea of considering this third kind of effect is a creation of the Bagley decision. ${ }^{152}$ While Justice Blackmun identifies the presence of "adverse effects" as the rationale for treating specific requests favorably, the Agurs Court had justified favorable treatment for specific requests on other grounds. ${ }^{153}$

151. Conceiving of a hypothetical situation in which the defense could suffer this third form of adverse effect was difficult. This difficulty helps to illustrate that courts could rarely determine that the defense suffered additional adverse effects because the request was specific.

152. See infra notes $163-65$ and accompanying text.

153. See infra notes $154-62$ and accompanying text. 


\section{B. Fundamental Shift in Underlying Rationale: From Notice and Fairness to Adverse Effects of Nondisclosure.}

Under Brady-Agurs, courts only considered presentation and derivative adverse effects. ${ }^{154}$ In fact, neither Brady nor Agurs mention any adverse effects that result exclusively, or more often, in the specific request context. The presence of such additional adverse effects was not the reason why the Agurs Court provided a lower materiality standard for specific requests. Instead, Agurs endorsed a lower specific request standard because specific requests give prosecutors notice of precisely what the defense desires. ${ }^{155}$

According to the Agurs Court, a specific request simplifies the prosecutor's disclosure duty by giving notice of evidence that the defense lacks and believes to be valuable. ${ }^{156}$ Without a specific request, the prosecutor must peruse his files without direction. Thus, in the general/no request context, Agurs only required disclosure when evidence was "so clearly supportive of a claim of innocence that it [gave] the prosecution notice of a duty to produce." 157 On the other hand, specifically requested evidence, brought to the prosecutor's attention by the defense, need not be as self-evidently important. ${ }^{158}$ Therefore, a lower materiality standard was appropriate.

Commentators have suggested additional reasons for the Agurs holding that greater notice justifies applying a lower materiality standard $\mathrm{m}$ the specific request context. Professors LaFave and Israel believe that the Agurs decision "reflected the view that [in specific request cases], the prosecutor's responsibility for any resulting trial deception is clear."1s9 Professor Babcock agrees, arguing that a prosecutor's nondisclosure in response to a specific request "has the feel of imisdealing."160 Professor Babcock notes Justice Marshall's statement in his Agurs dissent that "[i]t is the presence of deliberate prosecutorial misconduct and a desire to deter such misconduct, presumably, that leads the Court to recognize a rule inore readily permitting new trials in cases involving a specific defense request for information."161 Also implicit in Agurs, Babcock contends, is the belief that if the defense works hard enough to provide proper notice, disclosure of specifically requested evidence seems less gra-

154. For a discussion of these effects, see supra notes 148-51 and accompanying text.

155. Agurs, 427 U.S. at 106-07.

156. Id.

157. Id. (emphasis added).

158. Id.

159. W. LAFAVE \& J. 1SRAEL, supra note 149 , § 19.5, at 757.

160. Babcock, supra note 38 , at 1149.

161. Id. at 1149-50 n.62 (quoting Agurs, 427 U.S. at 121 n.7 (Marshall, J., dissenting)). 
tuitous and thus less of an intrusion on the adversary system. ${ }^{162}$

The Bagley majority, however, approached the distinction between specific and general requests from a new perspective. The majority never acknowledged that the Agurs Court treated specific requests more favorably because of the greater degree of notice in the specific request context and perhaps also because of notions of fairness and prosecutorial misdealing. Instead, the Bagley majority articulated a new reason for favorable treatment of specific requests, adopting the government's argument that the only rationale inferable from Agurs for applying a lower materiahity standard in specific request cases was the additional adverse effects arising in the specific request context. ${ }^{163}$ The government had expressly rejected the contention that the Agurs Court intended the degree of notice to serve as the rationale for applying different materiality standards. ${ }^{164}$

Believing that such additional adverse effects constituted the only rationale for a separate, more inclusive specific request materiality standard, Justice Blackmun found that rationale inadequate and concluded that reviewing courts could compensate for these additional adverse effects by simply considering their impact on the trial result. ${ }^{165}$ Thus, the Court jettisoned the Brady-Agurs two-part test in favor of a single flexible standard, with Justice Blackmun assuming that lower courts would be able to use the single flexible standard to account for the additional adverse affects that might arise in the specific request context. The concept of additional adverse effects peculiar to nondisclosure following a specific request thus emerged from the Bagley decision.

\section{The Bagley Materiality Theory in Practice.}

Taken together, the Bagley opinions instruct the lower courts to engage in an inquiry into adverse effects peculiar to nondisclosure following specific requests for evidence. ${ }^{166}$ These adverse effects supposedly occur because nondisclosure in the specific request context misleadingly represents to the defense that the requested evidence does not exist. Because reviewing courts are to consider these adverse effects, a specific request for undisclosed evidence theoretically bolsters the defense case. A close examination of these purported adverse effects, lowever, reveals that

162. Id.

163. Brief for the United States at 21-22, United States v. Bagley, 105 S. Ct. 3375 (1984) (No. 84 48).

164. Id. The brief acknowledged that nondisclosure may mislead the defense into believing the requested evidence does not exist. Id. at 31.

165. See supra notes 107-09 and accompanying text.

166. See supra notes 104-09 and accompanying text. 
they are no more likely to occur after a specific request than after a general request and that, therefore, the defendant armed with a specific request has no advantage in proving materiality over a defendant who made only a general request. Moreover, a close examination also reveals that a court's consideration of the adverse effects of a nondisclosure's misleading representation to the defense that the evidence does not exist will never help the defense prove materiality. Therefore, Bagley's required inquiry not only provides no advantage for specific requests over general requests but also completely fails to advance the defense case in proving materiality.

As discussed above, Justice Blackmun concluded that a court's consideration of adverse effects arising from a nondisclosure's misleading representation that evidence does not exist would be more beneficial to the defense in proving materiality after a specific request than after a general request. This conclusion is incorrect because it is based on the faulty assumption that the defense is more likely to expect disclosure after a specific request. This assumption ignores the fact that, unlike the Brady-Agurs specific request standard, the Bagley materiality standard gives the defense no reason to believe that a specific request makes disclosure more likely. Under Brady-Agurs, a specific request triggered a lower materiality standard and tlius a greater prosecutorial disclosure duty. ${ }^{167}$ Thus, the defense under Brady-Agurs could reasonably expect that the prosecutor was more likely to disclose evidence if it was specifically re-

167. It is well-settled that the prosecutor only has a constitutional duty to disclose material evidence. See United States v. Bagley, $105 \mathrm{~S}$. Ct. at 3379 (opinion of Blackmun, J., joined by O'Connor, J.) (citing Brady, 373 U.S. at 87). Prosecutors, therefore, can only be expected to disclose evidence not seen as material if they play it safe and interpret their legal duty broadly. Such a response is unlikely. As Justice Marshall and Justice Stevens each argue in their Bagley dissents, prosecutors will not disclose but gamble that the defense will never realize evidence was suppressed, or that the evidence will not meet the high materiality standard upon judicial review. Id. at 3393 (Marshall, J., dissenting); id. at 3400 (Stevens, J., dissenting). Professor Babcock agrees, and reported the following anecdote by Jon O. Newman, then United States Attorney for Connecticut (now a judge on the United States Court of Appeals for the Second Circuit), to the Judicial Conference of the Second Circuit:

I recently had occasion to discuss [disclosure under Brady] at a PLI Conference in New York City before a large group of State prosecutors. I put to them this case: You are prosecuting a bank robbery. You have talked to two or three of the tellers and one or two of the customers at the time of the robbery. They have all taken a look at your defendant in a line-up, and they have said, "This is the man." In the course of your investigation you also have found another customer who was in the bank that day, who viewed the suspect, and came back and said, "That is not the man."

The question I put to the prosecutors was, do you believe you should disclose to the defense the name of the witness who, when he viewed the suspect, said "That is not the man'? In a room of prosecutors not quite as large as this group but almost as large, only two hands went up. ... . Yet I was putting to them what I thought was the easiest casethe clearest case for disclosure of exculpatory information!

Discovery in Criminal Cases, 44 F.R.D. 481, 500 (1967), quoted in Babcock, supra note 38, at 1167 n.123. 
quested. In contrast, under Bagley, a specific request triggers no lower materiality standard and thus no greater prosecutorial disclosure duty. ${ }^{168}$ It would simply be illogical for defense attorneys to lave any greater expectation that the prosecutor will disclose in the specific request context than in the general/no request context. It follows that defense attorneys, having made a specific request, are no more likely to mistakenly assume from the fact of nondisclosure tliat the evidence does not exist. ${ }^{169}$

Justice Blackmun's analysis is faulty in another respect. Justice Blackmun assumed that a court's consideration of the adverse effects of a nondisclosure's misleading representation that no evidence exists could in some cases contribute to a finding of materiality. But this assumption is unfounded. The prosecutor's nondisclosure following a specific request can only be interpreted by the defense in one of two ways: (1) the prosecutor did not liave the requested evidence, or (2) the prosecutor did not believe the evidence was material and tlus did not disclose. For the defense rationally to conclude from nondisclosure that the prosecutor did not liave the evidence, and thus be misled, the defense would have to be thorouglily convinced that the materiality of the requested evidence was so completely beyond question that no prosecutor would risk nondisclosure.

If one accepts, lowever, that only sucli self-evidently material evidence would justify a defendant's claim of being misled, it becomes apparent that this added adverse effect is superfluous. If a reviewing court decides that the evidence at the time of review is not material, the court must find that the defense sliould not have been misled by the nondisclosure. Conversely, if the reviewing court decides that the evidence at the time of review is material, the defense could indeed lave been misled; this would be of no consequence, lowever, because the reviewing court would reverse in any event due to the inherent materiality of the evidence itself. Thus, because the defense is reasonably misled only when the evi-

168. Justice Blackmun may have assumed that a specific request does require a greater prosecutorial disclosure duty. In his opinion, he quotes Agurs: "When the prosecutor receives a specific and relevant request, the failure to make any response is seldom, if ever, excusable." Bagley, 105 S. Ct. at 3383 (quoting Agurs, 427 U.S. at 106). The Agurs Court justified this assertion by emphasizing that a specific request gives the prosecutor notice. See Agurs, 427 U.S. at 106; see also Babcock, supra note 38, at 1148-49. Justice Blackmun at one point acknowledged that "the more specifically the defense requests certain evidence, thus putting the prosecutor on notice of its value, the more reasonable it is for the defense to assume from nondisclosure that the evidence does not exist." Bagley, 105 S. Ct. at 3384 (emphasis added). Justice Blackmun thus recognized the Agurs Court's correlation between better notice and a greater duty to disclose in the specific request context. Under Bagley, there is no lower specific request materiality standard; thus, better notice, in and of itself, creates no greater duty to disclose.

169. This note assumes that a reviewing court would apply an objective standard; in other words, a defense attorney must be reasonably misled. 
dence is material, any additional adverse effects to the defense from having been misled will never affect a reviewing court's decision on materiality.

Justice Blackmun's standard is thus founded on two incorrect conclusions: (1) the conclusion that, in the specific request context, the defense is more likely to suffer adverse effects from being misled, and (2) the conclusion that the adverse effects froun being misled could ever influence a reviewing court's determination of materiahity. The reviewing courts that follow the Bagley rule and thus search for such additional adverse effects are in effect engaged in a futile enterprise. The practical effect of the Bagley rule is to eliminate all distinction between specific and general/no request situations and reduce the inquiry to the consideration of presentation and derivative effects.

\section{CONCLUSION}

The Bagley Court replaced the two-tiered Brady-Agurs framework with a single standard designed to cover both specific and general/no requests. In so doing, the Court ignored the notice and fairness rationales underlying the more favorable Brady-Agurs specific request standard. Instead, the Court identified another concern as being central: that the defense suffers additional adverse effects from nondisclosure following a specific request. To address this concern, Justice Blackmun, in what inust be seen as the effective holding on this issue, instructed lower courts to consider the special adverse effects suffered by the defense in the specific request context. This additional consideration theoretically preserves an advantage for defendants makmg specific requests. Accordingly, soine lower courts have required a search for the special adverse effects arising because the request was specific.

Under the single materiality standard, however, these special adverse effects in fact do not exist. The efforts of lower courts to follow Bagley's instructions to treat specific requests favorably by considering such adverse effects will thus always be futile. Although in theory it preserves an advantage for defendants making specific requests, the Bagley materiality standard will effectively treat specific and general/no requests in the saine inanner.

Bagley's effective equal treatment of specific and general/no requests runs counter to the intentions of at least five Justices (Blacknnun, O'Connor, Stevens, Marshall, and Brennan), each of whoin indicated that specific requests should receive favorable treatinent. In addition, the equal treatınent of specific and general/no requests represents a reversal of the Brady-Agurs materiality franework without any consideration by the Supreine Court of the notice and fairness rationales underlying that 
framework. The initial lower court response to Bagley has been marked by a good deal of confusion. For these reasons, the Court should reconsider Bagley and decide whether the notice and fairness rationales are convincing. Unless the Court believes that its own reasoning in Agurs is without merit, the Court should reinstate the Brady-Agurs materiality framework. Only by so doing can the Court once again provide an effective advantage for defendants making specific requests for favorable evidence. 